\title{
Variations in sugars and cyclitols during development and maturation of seeds of brazilwood (Caesalpinia echinata Lam., Leguminosae)
}

\author{
Igor F. Borges ${ }^{1}$, Claudio J. Barbedo ${ }^{2}$, Andreas A. Richter ${ }^{3}$ and Rita de Cássia L. Figueiredo- \\ Ribeiro $^{2 *}$ \\ ${ }^{1}$ BASF S.A., Agricultural Products, Estr. Samuel Aizemberg, 1707, Bloco C, 09851-550 São Bernardo do Campo, SP, Brazil. \\ ${ }^{2}$ Instituto de Botânica, C.P. 3005, 01061-970 São Paulo, SP, Brazil . ${ }^{3}$ Department of Chemical Ecology and Ecosystem Research, \\ University of Vienna, A-1090 Wien, Austria. *Corresponding author: ritarib@usp.br
}

Received: 24 October 2006; Returned for revision: 24 January 2007; Accepted: 10 February 2007

Seeds of Caesalpinia echinata are tolerant to desiccation, keeping their viability up to $0.08 \mathrm{~g} \mathrm{H}_{2} \mathrm{O} \mathrm{g}^{-1} \mathrm{DM}$. When stored under laboratory conditions they lose their viability within one month, while under low temperatures germination ability is maintained during two years of storage. Here, we report on the variations of soluble carbohydrates, cyclitols and cyclitol galactosides in seeds of $C$. echinata during development and maturation, aiming for a better understanding of the involvement of these compounds in the maturation process and seed quality. Individual flowers were tagged on the day of anthesis and pods were collected directly from the branches from 32 to $59 \mathrm{~d}$ after anthesis (DAA). Seeds were also collected after shedding. The physiological maturity of $C$. echinata seeds occurred 60-65 DAA, immediately before shedding, when seeds had $0.43-0.67 \mathrm{~g} \mathrm{H}_{2} \mathrm{O} \mathrm{g}^{-1} \mathrm{DM}$. Soluble carbohydrates made up about $10 \%$ of the seed dry mass. Gas chromatography and mass spectrometry allowed the identification and quantification of 12 soluble carbon compounds present in both the axis and cotyledons of developing C. echinata seeds. These included fructose, glucose, sucrose, raffinose, the cyclitols myo-inositol, D-chiro-inositol, D-pinitol, and the cyclitol galactosides, galacto-pinitol A, galacto-pinitol B and ciceritol. Sucrose was present in high proportions in both tissues during seed development. Traces of raffinose were also detected, mainly in immature seeds. D-chiro-inositol and myo-inositol were found in low amounts and pinitol transiently increased in both axis and cotyledons. Ciceritol, galacto-pinitol A and galacto-pinitol B accumulated from 40 DAA to the end of seed maturation, representing along with sucrose the major carbon reserves of $C$. echinata seeds. These results allowed us to conclude that variations in soluble carbon reserves of $C$. echinata seeds were related to the maturation process and seed quality.

Key words: seed development, seed viability, soluble carbohydrates

Variações nos açúcares e ciclitóis durante o desenvolvimento e maturação de sementes de pau-brasil (Caesalpinia echinata Lam., Leguminosae). Sementes de Caesalpinia echinata são tolerantes à dessecação, mantendo sua viabilidade com níveis de $0,08 \mathrm{~g} \mathrm{H}_{2} \mathrm{O}$ $\mathrm{g}^{-1}$ MS. Quando armazenadas sob condições de laboratório perdem a viabilidade em um mês, enquanto sob baixas temperaturas a capacidade germinativa é mantida por dois anos. A concentração e a composição de açúcares solúveis, ciclitóis livres e ciclitóis galactosilados durante o desenvolvimento e a maturação dessas sementes foram analisadas no presente trabalho, com o propósito de compreender-se o envolvimento daqueles compostos na maturação e na qualidade da semente. Inflorescências foram marcadas na antese e posteriormente coletadas desde 32 até $59 \mathrm{~d}$ após antese (DAA) e após a deiscência. A maturidade fisiológica de sementes de C. echinata ocorreu entre 60-65 DAA, imediatamente antes da dispersão, quando as sementes apresentavam 0,43-0,67 g $\mathrm{H}_{2} \mathrm{O}$ $\mathrm{g}^{-1}$ MS. Carboidratos solúveis totais corresponderam a cerca de $10 \%$ da matéria seca das sementes. Análises por cromatografia gasosa e espectroscopia de massas permitiram quantificar 12 compostos presentes nos eixos e cotilédones durante o desenvolvimento das sementes. Estes incluem frutose, glicose, sacarose, rafinose, os ciclitóis mio-inositol, D-chiro-inositol, D-pinitol e os ciclitóis galactosilados, galacto-pinitol A, galacto-pinitol B e ciceritol. Sacarose foi detectada em grandes proporções durante todo o processo de desenvolvimento das sementes. Traços de rafinose foram detectados, principalmente em sementes imaturas. D-chiroinositol e mio-inositol foram encontrados em baixas quantidades e pinitol aumentou de forma contínua nos eixos e nos cotilédones. Ciceritol, galacto-pinitol A e galacto-pinitol B foram acumulados de 40 DAA até o final da fase de maturação, representando, com a sacarose, as maiores reservas de carboidratos solúveis das sementes de $C$. echinata. Estes resultados permitem concluir que o acúmulo de reservas solúveis de carbono está relacionado com o grau de maturação das sementes de C. echinata e com qualidade final dessas sementes.

Palavras-chave: carboidratos solúveis, desenvolvimento de sementes, viabilidade de sementes 


\section{INTRODUCTION}

Caesalpinia echinata Lam. (brazilwood, pernambuco-wood) is a tree species native to the Brazilian Atlantic coast and occurs mainly in areas of dry seasonal forests (Lira et al., 2003). It is an endangered species (Ibama, 1992), having been used as dyestuff in the past and currently it is still utilized for the manufacturing of high-quality bows of string instruments (Lewis, 2001; Rocha, 2004). Various proteinase inhibitors, including trypsin, elastase and human plasma kallikrein inhibitors (Oliveira et al., 2002; Cruz-Silva et al., 2004) were isolated from seeds of $C$. echinata, suggesting that these seeds could also be used to study the role of important enzymes in pathophysiological processes.

Mature seeds of $C$. echinata contain $30-40 \%$ starch and $10-15 \%$ of soluble carbohydrates, predominantly sucrose and trace amounts of raffinose and stachyose (Garcia et al., 2006). These seeds are tolerant to desiccation, keeping their viability up to $0.08 \mathrm{~g} \mathrm{H}_{2} \mathrm{O} \mathrm{g}^{-1}$ MS after drying at $40-50^{\circ} \mathrm{C}$ (Barbedo et al., 2002). However, when these seeds are stored under laboratory environmental conditions $\left(22 \pm 7^{\circ} \mathrm{C}\right)$ they lose their viability within one month. When stored at low temperatures $\left(7 \pm 1^{\circ} \mathrm{C}\right)$, however, germination is maintained during 18 months of storage (Barbedo et al., 2002). Changes in soluble sugars during storage suggested that the loss of germinability of $C$. echinata seeds could be associated with low levels of glucose and fructose in relation to sucrose (Garcia et al., 2006).

Among other cell compounds, soluble carbohydrates are involved in desiccation tolerance during seed development and maturation (Obendorf, 1997; Hoekstra et al., 2001). Accumulation of sucrose and raffinose family oligosaccharides (RFO) during seed development has been proposed as a key factor in membrane stabilization (Caffrey et al., 1988) besides other physiological roles (Horbowicz et al., 1998 and references therein). Free cyclitols and galactosyl cyclitols are also accumulated in some seeds, and they have also been proposed to contribute to the structural stability of organelles, membranes, enzymes and other macromolecules, and the glassy state (Obendorf, 1997; Peterbauer and Richter, 2001).

The potential interactions among cyclitols and RFO during seed maturation and their role in seed quality and storability have been proposed for a number of legume species (Obendorf, 1997; Peterbauer and Richter, 2001). However, their precise role during seed development has not been reported yet. Here we report on the composition of soluble carbohydrates, cyclitols and cyclitol galactosides in cotyledons and in the embryonic axis of C. echinata seeds during development and maturation, aiming for a better understanding of their role in the seed quality of this species.

\section{MATERIAL AND METHODS}

Plant material: The experiments were carried out during 2001 in a homogeneous plantation ( $c a .250$ trees) located in the Biological Reserve and Experimental Station at Moji-Guaçu (22 ${ }^{\circ} 15-16^{\prime}$ S, 478 $-12^{\prime}$ W), State of São Paulo, Brazil. During the flowering period (August/September), individual flowers were tagged on the day of their anthesis (9 to 14 September). During the main phases of seed development (Borges et al., 2005), the pods were collected directly from the branches at 32, 40, 48, 52 and $59 \mathrm{~d}$ after anthesis (DAA) which is just before shedding (60-65 DAA). Seeds were also collected directly from the ground, not exceeding $24 \mathrm{~h}$ after shedding, and these were named recently-dispersed seeds (RDS).

Analysis of seed quality: The water content (\%, on a fresh mass basis) and dry mass (mg seed $\left.{ }^{-1}\right)$ for each stage of development was determined by weight loss after drying during $24 \mathrm{~h}$ at $105 \pm 3^{\circ} \mathrm{C}$ (Brasil, 1992 - Brazilian Rules for Seed Testing) using four replicates of three to ten seeds each. The results were expressed as $\mathrm{g} \mathrm{H}_{2} \mathrm{O} \mathrm{g}^{-1} \mathrm{DM}\left(\mathrm{g} \mathrm{g}^{-1}\right)$. Germination (protrusion of the primary root) tests were carried out at $25 \pm 1{ }^{\circ} \mathrm{C}$ under continuous light, in germination boxes $(11 \times 11 \times 3.5 \mathrm{~cm})$ on two pieces of thick germination paper saturated with distilled water (Barbedo, 2005), using four replicates of 16 seeds. Germination was evaluated every $2 \mathrm{~d}$ from the day of sowing and after $20 \mathrm{~d}$ the number of seedlings with both normal roots and shoots was registered (Barbedo, 2005).

Extraction and analysis of soluble carbohydrates and cyclitols: Five to eight embryos of seeds harvested at 32, 40, 48, 52 and 59 DAA were separated into axis and cotyledons and soluble carbohydrates and cyclitols were analyzed. Immediately after excision both tissues were boiled in $80 \%$ ethanol ( $/ \mathrm{v})$, homogenized using a mortar 
and pestle, and heated at $80^{\circ} \mathrm{C}$ during $10 \mathrm{~min}$. After centrifugation for $5 \mathrm{~min}$ at $1000 \mathrm{~g}$, the residue was reextracted twice with $80 \%$ ethanol during $5 \mathrm{~min}$ at $80^{\circ} \mathrm{C}$ and once with water for $5 \mathrm{~min}$ at $60^{\circ} \mathrm{C}$. The ethanolic and aqueous extracts were pooled, evaporated to dryness and stored over $\mathrm{P}_{2} \mathrm{O}_{5}$. Gas chromatography and mass spectrometry (GC-MS, Saturn 2000 ion-trap mass spectrometer, Varian Inc., Vienna, Austria and GC 6890 Series Plus Agilent System, MS 5973 Agilent, USA) of soluble carbohydrates and cyclitols was performed for the axis and cotyledons after derivatization with trimethylsilyl trifluoro acetamide as previously described (Richter et al., 1990), except for 32 DAA.

Neutral soluble carbohydrates were additionally analyzed by high performance anion exchange chromatography coupled with pulsed amperometric detection (HPAEC/PAD Dionex DX-300, USA) after deionization through a column consisting of equal amounts of Dowex-1 ( $\mathrm{Cl}^{-}$form) and Dowex-50W ( $\mathrm{H}^{+}$form). The HPAEC/PAD system used consisted of a 4 x $250 \mathrm{~mm}$ CarboPac PA-1 column, eluted by a linear gradient of 25 mol m $\mathrm{m}^{-3}$ to $500 \mathrm{~mol} \mathrm{~m}^{-3}$ sodium acetate in $150 \mathrm{~mol} \mathrm{~m}^{-3}$ sodium hydroxide at a flow rate of $1 \mathrm{~mL} \mathrm{~min}^{-1}$ as established by Garcia et al. (2006). Sugars were identified by co-chromatography with authentic standards purchased from Sigma/Aldrich Co. (USA).

Overall, carbohydrates in the extracts were estimated colorimetrically by the phenol-sulfuric method (Dubois et al., 1956) using glucose as standard and were expressed as $\mathrm{g} \mathrm{kg}^{-1} \mathrm{FM}$.

Statistical analysis: The factorial analysis was carried out using the $\mathrm{F}$ test and Tukey's test $(P<0.05)$ to determi- ne the interaction and significant differences of age and tissue origin (axes and cotyledons) in relation to sugars and cyclitols after GC/MS analysis. Tukey's test $(P<$ 0.05 ) was also used to compare water content, dry and fresh mass, germination and normal seedling development (Pimentel-Gomes, 1990).

\section{RESULTS}

The patterns of development and maturation of $C$. echinata seeds under field conditions have been described recently (Borges et al., 2005). Table 1 indicates that maximum seed fresh and dry masses were reached nearly 60 DAA, the water content remaining practically constant during the early growth phase (till 40 DAA) and then declining slowly during the desiccation phase. Germinability of these seeds began at 40 DAA, reaching a maximum at 48 DAA, remaining high from this phase. However, normal seedling development was observed only at 59 DAA (Table 1), close to seed shedding (Borges et al., 2005). This indicates that the last desiccation phase (from 48 DAA to 59 DAA) is crucial to improve seed vigor.

During seed development and maturation the concentration of total soluble carbohydrates was higher in the cotyledons than in the axis, except at 48 DAA, when the amount of sugars increased significantly in the embryonic axis (Figure 1). This could be related to variations in the axis dry matter (data not shown). Maximal germination capacity was observed from this growth phase onwards, indicating the beginning of embryo maturation.

Analysis by HPAEC/PAD showed that sucrose, glucose and fructose were the major neutral soluble

Table 1. Physiological data (water content, germination, normal seedlings, and fresh and dry mass) of Caesalpinia echinata seeds during development and maturation from 32 to $59 \mathrm{~d}$ after anthesis (DAA). Within each column, means followed by the same letter do not differ significantly (Tukey's test, $P<0.05, n=4$ ).

\begin{tabular}{cccccr}
\hline DAA & $\begin{array}{c}\text { Water content } \\
(\%)\end{array}$ & $\begin{array}{c}\text { Germination } \\
(\%)\end{array}$ & $\begin{array}{c}\text { Normal seedlings } \\
(\%)\end{array}$ & $\begin{array}{c}\text { Fresh mass } \\
\left(\mathrm{mg} \mathrm{seed}^{-1}\right)\end{array}$ & $\begin{array}{c}\text { Dry mass } \\
\left(\mathrm{mg} \mathrm{seed}^{-1}\right)\end{array}$ \\
\hline 32 & $76.8 \mathrm{a}$ & $0 \mathrm{c}$ & $0 \mathrm{~b}$ & $34.5 \mathrm{e}$ & $8.0 \mathrm{e}$ \\
40 & $77.7 \mathrm{a}$ & $42 \mathrm{~b}$ & $0 \mathrm{~b}$ & $173.5 \mathrm{~d}$ & $38.8 \mathrm{~d}$ \\
48 & $64.6 \mathrm{~b}$ & $94 \mathrm{a}$ & $0 \mathrm{~b}$ & $283.8 \mathrm{c}$ & $100.5 \mathrm{c}$ \\
52 & $62.7 \mathrm{~b}$ & $100 \mathrm{a}$ & $0 \mathrm{~b}$ & $342.0 \mathrm{~b}$ & $127.0 \mathrm{~b}$ \\
59 & $45.4 \mathrm{c}$ & $97 \mathrm{a}$ & $89 \mathrm{a}$ & $458.8 \mathrm{a}$ & $250.2 \mathrm{a}$ \\
\hline
\end{tabular}




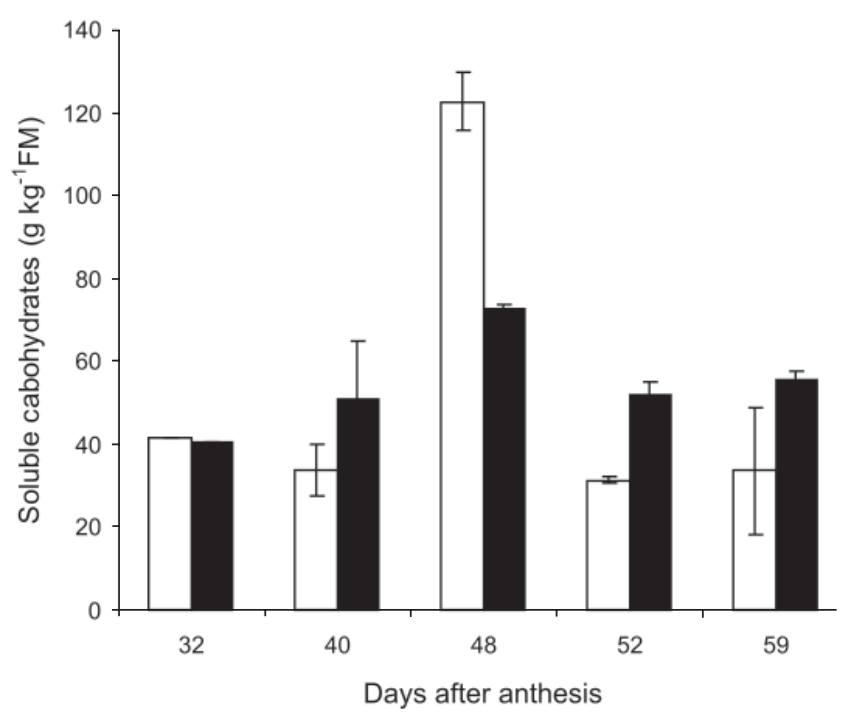

Figure 1. Soluble carbohydrates ( $\left.\mathrm{g} \mathrm{kg}^{-1} \mathrm{FM}\right)$ in the embryonic axis (white columns) and cotyledons (black columns) of Caesalpinia echinata seeds during development and maturation from 32 to $59 \mathrm{~d}$ after anthesis. Bars indicate SE $(n=3)$.

carbohydrates present in both the axis and cotyledons of C. echinata seeds (Figure 2). Raffinose was detected mainly in the axis at the beginning of seed growth (32 DAA). During seed development, the proportion of sucrose remained unchanged in the axis, while glucose and fructose, and raffinose, all decreased substantially from 40 DAA to 59 DAA. Hence, the proportion of sucrose in the axis was higher than that of monosaccharides during the maturation phase of $C$. echinata seeds (Figure 2). Similar variations were observed in the cotyledons, except at the beginning of seed growth (32 DAA till 40 DAA), when the proportions of glucose and fructose were higher than that of sucrose. A sharp decrease in monosaccharides was observed from 48 DAA onwards. HPAEC/PAD also showed the presence of myo-inositol (identified by co-chromatography with the authentic standard) and other non-identified compounds in both axis and cotyledons of $C$. echinata seeds in all developmental phases (Figure 2).

Twelve soluble carbon compounds in both the axis and cotyledons of developing $C$. echinata seeds were identified and quantified through GC/MS. These included fructose, glucose, sucrose, raffinose, the free cyclitols myo-inositol, D-pinitol, D-chiro-inositol, and the galactosyl cyclitols ciceritol, galacto-pinitol A and galacto-pinitol B (Tables 2-4).

Confirming HPAEC/PAD, the GC/MS analysis generally showed that fructose and glucose were present in low amounts, mainly in immature seeds both in axes and cotyledons (Table 2). In the axes fructose increased until 52 DAA and decreased from this age onwards, while glucose remained unchanged. In the cotyledons, the amount of both sugars decreased from 40 to 48 DAA. Sucrose was presented in high amounts in both tissues during seed development. Traces of raffinose were also detected without significant changes during the period analyzed (Table 2).

D-chiro-Inositol and myo-inositol were found in lower amounts than those of pinitol (Table 3). This free cyclitol was present in higher concentrations, mainly in embryonic axes, increasing consistently until 52 DAA (Table 3), when germination reached 100\% (Table 1).

Galactosyl cyclitols were present in large amounts in maturing $C$. echinata seeds and accumulated consistently from 40 DAA to the end of seed maturation, both in the axis and cotyledons, mainly as galacto-pinitol A, B and ciceritol (Table 4). These compounds represented along with sucrose the major carbon reserves of $C$. echinata seeds, mainly after shedding. The accumulation of these galactosyl cyclitols, especially ciceritol, was accompanied by a decline of pinitol after 52 DAA (Tables 3 and 4).

\section{DISCUSSION}

Maturation proteins, sucrose and RFO have been proposed to be the most important factors in the acquisition of desiccation tolerance (Blackmann et al., 1992). According to Han et al. (1997) desiccation tolerance is acquired during development of orthodox seeds when not only sugars are accumulated but also dehydrin-related polypeptides. In legume seeds, RFO are present in relatively large quantities (Horbowicz and Obendorf, 1994). However, these sugars were practically absent in mature whole seeds of $C$. echinata, accumulating $10-15 \%$ of their dry mass as soluble carbohydrates. Analysis of sugars during storage under different temperature conditions showed low levels of glucose and fructose in relation to sucrose in seeds of $C$. echinata that had lost germinability (Garcia et al., 2006), 
Embryonic axis

Cotyledons

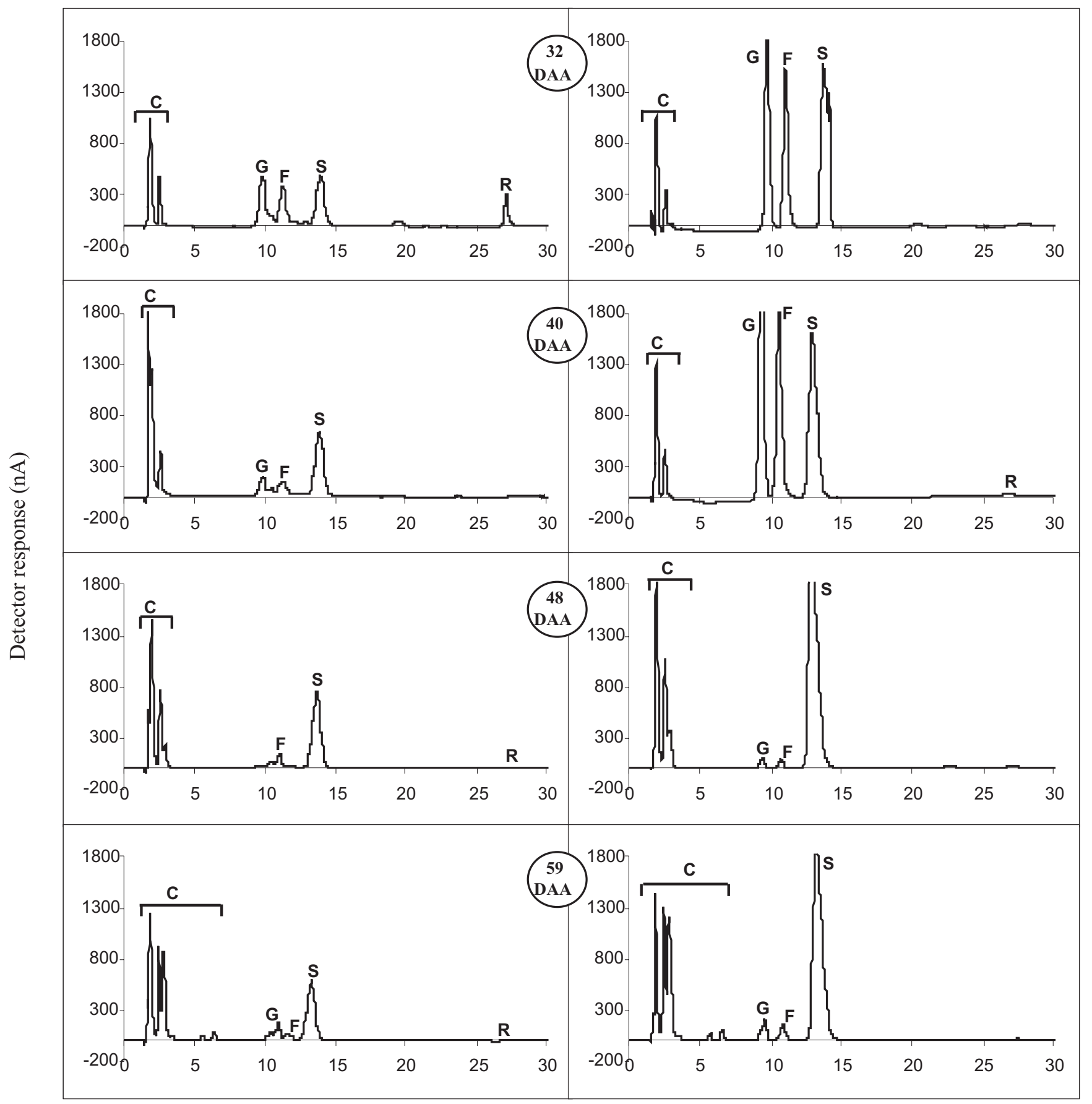

Elution time (min)

Figure 2. HPAEC/PAD profile of neutral soluble carbohydrates from axes (left) and cotyledons (right) of seeds of Caesalpinia echinata during development and maturation from 32 to $59 \mathrm{~d}$ after anthesis (DAA). C - cyclitols; G glucose; F - fructose; S - sucrose; R - raffinose. Samples contained $260 \mu \mathrm{g}$ and $800 \mu \mathrm{g}$ total sugar $\mathrm{mL}^{-1}$ for the embryonic axis and cotyledons, respectively. 
Table 2. Soluble carbohydrates ( $\left.\mathrm{g} \mathrm{kg}^{-1} \mathrm{FM}\right)$ in axes and cotyledons of Caesalpinia echinata during different developmental phases (days after anthesis - DAA) and in recently-dispersed seeds (RDS). Means followed by the same letter, small in columns and capital in lines, do not differ significantly (Tukey's test, $P<0.05, n=3$ ). When factorial analysis of variance indicated that interactions were not significant, only the means of treatments were compared.

\begin{tabular}{|c|c|c|c|c|c|c|}
\hline \multirow{2}{*}{ Plant material } & \multicolumn{4}{|c|}{ DAA } & \multirow{2}{*}{ RDS } & \multirow{2}{*}{ Means } \\
\hline & 40 & 48 & 52 & 59 & & \\
\hline \multicolumn{7}{|c|}{ Fructose } \\
\hline Axis & $1.70 \mathrm{bC}$ & $5.56 \mathrm{aAB}$ & $7.69 \mathrm{aA}$ & $3.00 \mathrm{aBC}$ & $2.81 \mathrm{aC}$ & 4.15 \\
\hline Cotyledons & $5.64 \mathrm{aA}$ & $1.57 \mathrm{bB}$ & $3.91 \mathrm{AB}$ & $1.69 \mathrm{aB}$ & $2.96 \mathrm{aB}$ & 3.21 \\
\hline Means 40 & 3.67 & 3.72 & 5.80 & 2.34 & 2.88 & \\
\hline \multicolumn{7}{|c|}{ Glucose } \\
\hline Axis & $0.11 \mathrm{bA}$ & $0.04 \mathrm{aA}$ & $0.04 \mathrm{aA}$ & $0.04 \mathrm{aA}$ & $0.07 \mathrm{aA}$ & 0.06 \\
\hline Cotyledons & $2.79 \mathrm{aA}$ & $0.03 \mathrm{aB}$ & $0.03 \mathrm{aB}$ & $0.03 \mathrm{aB}$ & $0.02 \mathrm{aB}$ & 0.58 \\
\hline Means 40 & 1.45 & 0.04 & 0.03 & 0.03 & 0.04 & \\
\hline \multicolumn{7}{|c|}{ Sucrose } \\
\hline Axis & 5.59 & 20.67 & 20.07 & 10.69 & 24.43 & $16.29 \mathrm{a}$ \\
\hline Cotyledons & 21.90 & 21.65 & 20.10 & 18.15 & 25.73 & $21.50 \mathrm{a}$ \\
\hline Means 40 & $13.74 \mathrm{~A}$ & $21.16 \mathrm{~A}$ & $20.08 \mathrm{~A}$ & $14.42 \mathrm{~A}$ & $25.08 \mathrm{~A}$ & \\
\hline \multicolumn{7}{|c|}{ Raffinose } \\
\hline Axis & 0.13 & 0.26 & 0.27 & 0.19 & 0.37 & $0.24 \mathrm{a}$ \\
\hline Cotyledons & 0.12 & 0.19 & 0.19 & 0.18 & 0.30 & $0.20 \mathrm{a}$ \\
\hline Means 40 & $0.13 \mathrm{~A}$ & $0.22 \mathrm{~A}$ & $0.23 \mathrm{~A}$ & $0.18 \mathrm{~A}$ & $0.33 \mathrm{~A}$ & \\
\hline
\end{tabular}

Table 3. Free-cyclitols ( $\mathrm{g} \mathrm{kg}^{-1} \mathrm{FM}$ ) in axes and cotyledons of Caesalpinia echinata during different developmental phases (days after anthesis - DAA) and in recently-dispersed seeds (RDS). Statistics as in Table 2.

\begin{tabular}{|c|c|c|c|c|c|c|}
\hline \multirow{2}{*}{ Plant material } & \multicolumn{4}{|c|}{ DAA } & \multirow{2}{*}{ RDS } & \multirow{2}{*}{ Means } \\
\hline & 40 & 48 & 52 & 59 & & \\
\hline \multicolumn{7}{|c|}{ Pinitol } \\
\hline Axis & 1.08 & 3.66 & 7.49 & 2.01 & 3.24 & $3.49 \mathrm{a}$ \\
\hline Cotyledons & 1.05 & 1.50 & 3.19 & 1.38 & 1.63 & $1.75 \mathrm{a}$ \\
\hline Means 40 & $1.06 \mathrm{~B}$ & $2.58 \mathrm{AB}$ & $6.34 \mathrm{~A}$ & $1.70 \mathrm{~B}$ & $2.43 \mathrm{AB}$ & \\
\hline \multicolumn{7}{|c|}{ D-chiro-Inositol } \\
\hline Axis & 0.21 & 0.48 & 0.45 & 0.24 & 0.18 & $0.31 \mathrm{a}$ \\
\hline Cotyledons & 0.13 & 0.26 & 0.17 & 0.12 & 0.13 & $0.16 \mathrm{a}$ \\
\hline Means 40 & $0.17 \mathrm{AB}$ & $0.37 \mathrm{~A}$ & $0.31 \mathrm{AB}$ & $0.18 \mathrm{AB}$ & $0.16 \mathrm{~B}$ & \\
\hline \multicolumn{7}{|c|}{ myo-Inositol } \\
\hline Axis & 0.20 & 0.51 & 0.41 & 0.20 & 0.15 & $0.29 \mathrm{a}$ \\
\hline Cotyledons & 0.48 & 0.32 & 0.22 & 0.12 & 0.08 & $0.24 \mathrm{a}$ \\
\hline Means 40 & $0.34 \mathrm{~A}$ & $0.41 \mathrm{~A}$ & $0.31 \mathrm{~A}$ & $0.16 \mathrm{~A}$ & $0.12 \mathrm{~A}$ & \\
\hline
\end{tabular}

suggesting that sucrose metabolism could be related to seed viability and the ratio monosaccharides to disaccharides an indication of this process. The decline in vigor of the maize embryo was associated with a marked decline in monosaccharides and in raffinose. In these seeds sucrose content remained relatively stable (Bernal-Lugo and Leopold, 1992), similar to that found in C. echinata seeds. However, the decline in monosacharides found during seed maturation of $C$. echinata seeds apparently was not associated with the germination capacity.
In Fagopyrum esculentum (buckwheat), instead of RFO, the seeds accumulate $\alpha$-galactosyl D-chiroinositols which may play a role in storability (Horbowicz et al., 1998; Steadman et al., 2000). Analysis of maturing seeds of $C$. echinata by GC/MS revealed the presence of substantial amounts of various cyclitols such as pinitol, ciceritol, and galacto-pinitol $\mathrm{A}$ and $\mathrm{B}$, which could have similar functions to RFO with respect to storability. As reported by Hellmann et al. (2006) the viability of these seeds can be maintained for up to two years when stored at sub-zero temperatures. Galactosyl cyclitols are 
Table 4. Galactosil-cyclitols ( $\mathrm{g} \mathrm{kg}^{-1} \mathrm{FM}$ ) in axes and cotyledons of Caesalpinia echinata during different developmental phases (days after anthesis - DAA) and in recently-dispersed seeds (RDS). Statistics as in Table 2.

\begin{tabular}{|c|c|c|c|c|c|c|}
\hline \multirow{2}{*}{ Plant material } & \multicolumn{4}{|c|}{ DAA } & \multirow{2}{*}{ RDS } & \multirow{2}{*}{ Means } \\
\hline & 40 & 48 & 52 & 59 & & \\
\hline \multicolumn{7}{|c|}{ Galacto-pinitol A } \\
\hline Axis & 0.06 & 3.71 & 12.13 & 14.77 & 14.21 & $8.98 \mathrm{a}$ \\
\hline Cotyledons & 0.83 & 3.24 & 5.50 & 10.02 & 5.70 & $5.06 \mathrm{a}$ \\
\hline Means 40 & $0.44 \mathrm{~A}$ & $3.48 \mathrm{~A}$ & $8.82 \mathrm{~A}$ & $12.40 \mathrm{~A}$ & $9.96 \mathrm{~A}$ & \\
\hline \multicolumn{7}{|c|}{ Galacto-pinitol B } \\
\hline Axis & 0.04 & 0.94 & 2.95 & 6.13 & 1.29 & $2.27 \mathrm{a}$ \\
\hline Cotyledons & 0.03 & 0.60 & 1.29 & 4.26 & 6.09 & $2.45 \mathrm{a}$ \\
\hline Means 40 & $0.04 \mathrm{~B}$ & $0.77 \mathrm{~B}$ & $2.12 \mathrm{AB}$ & $5.20 \mathrm{AB}$ & $8.69 \mathrm{~A}$ & \\
\hline \multicolumn{7}{|c|}{ Ciceritol } \\
\hline Axis & 0.04 & 5.41 & 21.74 & 63.57 & 45.59 & $25.27 \mathrm{a}$ \\
\hline Cotyledons & 0.22 & 5.38 & 13.13 & 33.76 & 29.66 & $16.43 \mathrm{a}$ \\
\hline Means 40 & $0.13 \mathrm{~B}$ & $5.40 \mathrm{AB}$ & $17.43 \mathrm{AB}$ & $43.67 \mathrm{~A}$ & $37.63 \mathrm{AB}$ & \\
\hline
\end{tabular}

frequently found in similar or even higher amounts than RFO in seeds of many important grain legumes, such as lentil, chickpea and soybean (Peterbauer and Richter, 1998) and share some common functions, including participation in the acquisition of desiccation tolerance (Peterbauer and Richter, 2001, and references therein).

Galactosyl cyclitols and RFO accumulation during seed drying and maturation may play a key protective role, replacing water and thus stabilizing membranes and other sensitive systems in the cell (Peterbauer and Richter, 2001). In the present study, pinitol and galactosyl cyclitols, in addition to sucrose, were identified in seeds of $C$. echinata (which are not sensitive to desiccation) accumulating mainly during the maturation phase.

A question that arises is whether these soluble carbon compounds are involved in embryo viability and seed vigor after shedding. In some seeds that have very low levels of RFO, as exemplified by $C$. echinata, galactosyl cyclitols may take on the role of those sugars. Loss of RFO and cyclitols in the axes of several leguminous seeds precede germination (Gorécki et al., 1997). The significant increase of galactosyl cyclitols at the end of the maturation phase of $C$. echinata seeds could be associated with the germination capacity and vigor of seeds (Tables 1 and 4), indicating a nutritive role for these compounds to seedling growth.

As recently reported (Hellmann et al., 2006), seeds of brazilwood are also freezing tolerant depending on their water content. In seeds of Erythrina caffra the high contents of inositols and monosaccharides were associated with the protection of plasma membranes from the effects of low temperatures (Nkang, 2002). Interesting variations in buckwheat embryos of seeds grown in cooler temperatures were reported by Horbowicz et al. (1998), sucrose being decreased and stachyose and the galactosyl cyclitol fagopyritol B1 increased. The effect of low temperatures on the content and composition of soluble carbohydrates and cyclitols in cotyledons and axes of $C$. echinata seeds could be important to an understanding of the involvement of these compounds in relation to their behavior during storage under different temperatures. The effect of low temperatures on individual polypeptides and lipids should be considered. Additionally, as emphasized by Borges et al. (2005), the role of the environment during development and maturation of seeds of $C$. echinata needs further investigation. However, results from the present study allow us to conclude that variations in soluble carbon reserves of $C$. echinata seeds are related to the maturation process and seed quality and might contribute to an understanding of the involvement of these compounds in the conservation of the seeds.

Acknowledgements: This work is part of the Master's thesis of I.F. Borges conducted within the Plant Biodiversity and Environment Program/Instituto de Botânica, SEMASP, São Paulo and supported by the State of São Paulo Research Foundation (FAPESP), through grants 00/06422-4 and 05/04139-7. C.J. Barbedo and R.C.L. Figueiredo-Ribeiro are holders of CNPq fellowships. Thanks are due to Mr O. Vieira for helpful advice with the English text. 


\section{REFERENCES}

Barbedo CJ (2005) Armazenamento e germinação de sementes de Caesalpinia echinata Lam. (pau-brasil). In: Nogueira RMC, Araújo EL, Willadino LG, Cavalcante UMT (eds), Estresses Ambientais: Danos e Beneficios em Plantas, vol. 1, pp.249-255. Imprensa Universitária, UFRPE, Recife.

Barbedo CJ, Bilia DA, Figueiredo-Ribeiro RCL (2002) Tolerância à dessecação e armazenamento de sementes de Caesalpinia echinata Lam. (pau-brasil), espécie da Mata Atlântica. Rev. Bras. Bot. 25:431-439.

Bernal-Lugo I, Leopold AC (1992) Changes in soluble carbohydrates during seed storage. Plant Physiol. 98:1207-1210.

Blackman SA, Obendorf RL, Leopold AC (1992) Maturation proteins and sugars in desiccation tolerance of developing soybean seeds. Plant Physiol. 100:225-230.

Borges IF, Del Giudice Neto J, Bilia DAC, FigueiredoRibeiro RCL, Barbedo CJ (2005) Maturation of seeds of Caesalpinia echinata Lam. (brazilwood), an endangered leguminous tree from the Brazilian Atlantic Forest. Braz. Arch. Biol. Technol. 48:851-861.

Brasil - Ministério da Agricultura (1992) Regras para análise de sementes. SNDA/DNDV/CLAV, Brasília.

Caffrey M, Foseca V, Leopold AC (1988) Lipid-sugar interactions: Relevance to anhydrous biology. Plant Physiol. 86:754-758.

Cruz-Silva I, Gozzo AJ, Nunes VA, Neuhof C, Neuhof H, Araújo MS (2004) Effect of inhibitors from Caesalpinia echinata on pulmonary edema. Proc. Braz. Soc. Biochem. Mol. Biol. 33:1.

Dubois N, Gilles KA, Hamilton JK, Rebers PA, Smith F (1956) Colorimetric method for determination of sugars and related substances. Anal. Chem. 28:350-356.

Garcia IS, Souza A, Barbedo CJ, Dietrich SMC, FigueiredoRibeiro, RCL (2006) Changes in soluble carbohydrates during storage of seeds of Caesalpinia echinata Lam. (brazilwood), an endangered leguminous tree from the Brazilian Atlantic Forest. Braz. J. Biol. 66:739-745.

Górecki RJ, Piotrowicz-Cieslak AI, Lahuta LB, Obendorf RL (1997) Soluble carbohydrates in desiccation tolerance of yellow lupin seeds during maturation and germination. Seed Sci. Res. 7:107-115.

Han B, Berjak P, Pammenter N, Farrant J, Kermode AR (1997) The recalcitrant plant species, Castanospermum australe and Trichilia dregeana, differ in their ability to produce dehydrin-related polypeptides during seed maturation and in response to ABA or water-deficitrelated stresses. J. Exp. Bot. 48:1717-1726.

Hoekstra FA, Golovina EA, Buitink J (2001) Mechanisms of plant desiccation tolerance. Trends Plant Sci. 6:431-438.
Horbowicz M, Obendorf RL (1994) Seed desiccation tolerance and storability: dependence on flatulenceproducing oligosaccharides and cyclitols - review and survey. Seed Sci. Res. 4:385-405.

Horbowicz M, Brenac P, Obendorf RL (1998) Fagopyritol B1, O-a-D-galactopyranosyl-(1@2)-D-chiro-inositol, a galactosyl cyclitol in maturing buckwheat seeds associated with desiccation tolerance. Planta 205:1-11.

IBAMA (1992) Instituto Brasileiro do Meio Ambiente e dos Recursos Naturais Renováveis, Portaria 37N, from 03 April 1992 (www.ibama.gov.br).

Lewis GP (2001) Caesalpinia: a revision of the Poincianella-Erythrostemon group. Royal Botanical Gardens, Kew.

Lira CF, Cardoso SRS, Ferreira PCG, Cardoso MA, Provan J (2003) Long-term population isolation in the endangered tropical tree species Caesalpinia echinata Lam. revealed by chloroplast microsatellites. Mol. Ecol. 12:3219-3225.

Nkang A (2002) Carbohydrate composition during seed development and germination in two sub-tropical tree species (Erythrina caffra and Guilfoylia monostylis). J. Plant Physiol. 159:473-483.

Obendorf RL (1997) Oligosaccharides and galactosyl cyclitols in seed desiccation tolerance. Seed Sci. Res. 7:63-74.

Oliveira LG, Gozzo AJ, Nunes VA, Cruz-Silva I, Sampaio MU, Sampaio CAM, Araújo MS (2002) Inibidores de proteases encontrados em sementes de Caesalpinia echinata (pau-brasil) - isolamento e caracterização do inibidor de tripsina. Rev. Bras. Farmac. 12:72-74.

Peterbauer T, Richter A (1998) Galactosyl ononitol and stachyose synthesis in seeds of adzuki bean. Purification and characterization of stachyose synthase. Plant Physiol. 117:165-172.

Peterbauer T, Richter A (2001) Biochemistry and physiology of raffinose family oligosaccharides and galactosyl cyclitols in seeds. Seed Sci. Res. 11:185-197.

Pimentel-Gomes F (1990) Curso de Estatística Experimental. Nobel, São Paulo.

Richter AA, Thonke B, Popp M (1990) 1D-1-O-methylmuco-inositol in Viscum album and members of the Rhizophoraceae. Phytochemistry 29:1785-1786.

Rocha YT (2004) Ibirapitanga: história, distribuição geográfica e conservação do pau-brasil (Caesalpinia echinata Lam., Leguminosae) do descobrimento à atualidade. São Paulo, University of São Paulo, PhD Thesis.

Steadman KJ, Burgoon MS, Schuster RL, Lewis BA, Edwardson SE, Obendorf RL (2000) Fagopyritols, D-chiroinositol and other soluble carbohydrates in buckwheat seed milling fractions. J. Agric. Food Chem. 48:2843-2847. 